WULS-SGGW, Warsaw, Poland

tomasz_rokicki@sggw.pl

ORCID iD: https://orcid.org/0000-0003-3356-2643

AleKsandra PerkowsKa

WULS-SGGW, Warsaw, Poland

aleksandra_perkowska@sggw.edu.pl

ORCID iD: https://orcid.org/0000-0002-7059-0689
DOI: $10.13166 / \mathrm{JMS} / 131860$

JOURNAL OF MODERN

SCIENCE TOM 2/45/2020,

S. $183-199$

PAULINA ZióŁKOWSKA

WULS-SGGW, Warsaw, Poland

paulina@mzsped.pl

ORCID iD: https://orcid.org/0000-0001-9140-8228

\title{
THE IMPORTANCE OF GRAINS TRANSPORT In Poland
}

\begin{abstract}
Grains transport is an activity that requires many procedures that affect the quality of the raw material being transported. Grains are transported by road, sea and rail. They are the subject of exchange on a local, national and international scale, being an important raw material for food processing.

The main purpose of the study was to present the importance of grains transport in Poland in total transport. Pearson's linear correlation was used for the analysis. The following methods were used for the analysis and presentation of materials: descriptive, tabular, graphic, dynamics indicators with a fixed and variable basis, Pearson's linear correlation coefficient, coefficient of variation.

The largest volume of grains was transported by road, then by sea and rail. However, the most important in a given branch were grains in maritime transport (from 3 to $9 \%$ of total transport in this branch), then in road (1-2\%) and rail. In the years 2007-2018, the volume of grain transported by road and rail increased the fastest, the level of transport by sea was maintained. The importance of ports in Gdynia and Swinoujście was systematically increasing, while the others were decreasing. There was a strong linear relationship between the volume of grain transported by road, rail and in total, and the economic situation in Poland.
\end{abstract}

KEYWORDS: grain, transport, modes of transport, sea ports, Gdańsk port 


\section{INTRODUCTION}

Grains are transported to processing plants, warehouses and mills, but also exported and imported. Products can be transported in bulk, in boxes, as well as in bags or on pallets (Berner et al., 2015, pp. 33-36). In Poland, most grain is transported in trucks due to their availability, functionality and mobility. In the era of optimizing inventory levels, enterprises decide on just-in-time deliveries and allocate goods directly to production. This reduces storage costs. Polish grains are an important component for the production of food materials in Europe. That is why more and more companies related to grain processing are investing in their plants in Poland (Szwedziak, Tukiendorf, 2015, pp. 6092-6099). As a consequence, grain transhipments made by Polish seaports are increasing. The marginal mode of transport is the use of railways. In general, there are many players in the grain supply chain. The limitation in turnover is the seasonality of production and orders (demand), warehouse space, requirements for means of transport (Mogale et al., 2017a, pp. 379-394; 2017b, pp. 80-97). Different models defining the grains supply chains are created, but the actual cost relationships influence the decisions of participants in such a chain. Enterprises also react very quickly to market signals. Transport companies are customers, they fulfill the demand reported by grains market participants (Gholamian and Taghanzadeh, 2017, pp. 139-147; Mogale et al., 2018, pp. 40-69; Naderi et al., 2019, pp. 1-21.).

\section{Aims AND RESEARCH METHODS}

The main objective of the study was to present the importance of grain transport in Poland in total transport. The specific objectives were: to show requirements for grain transport, to determine changes in grain transport by various modes of transport, to present links between grain transport and the economic situation as well as agricultural production results, including those related to grain. The research will help to fill the research gap. There is a lack of research relating to the importance of cereal transport in Poland, especially with regard to various branch of transport. The authors made the following research hypothesis: 
H1: There is a strong linear relationship between the volume of grain transported and the economic situation in Poland.

Secondary sources were used for the research, which mainly include studies and statistical data of the Central Statistical Office and national and international literature. The research concerned the years 2007-2018.

The following methods were used for the analysis and presentation of materials: descriptive, tabular, graphic, dynamics indicators with a fixed and variable basis, Pearson's linear correlation coefficient, coefficient of variation.

The dynamics indicators with a fixed base are determined as follows (Starzyńska, 2002, p. 102):

where :

$$
i=\frac{y_{n}}{y_{0}} \text { or } i=\frac{y_{n}}{y_{0}} \cdot 100 \%
$$

$y_{n}-$ the level of the phenomenon in a certain period,

$y_{0}-$ the level of the phenomenon during the reference period.

The dynamics indicators based on a variable basis are defined as follows (Starzynska, 2002, p. 102):

$$
i=\frac{y_{n}-y_{n-1}}{y_{n-1}} \text { or } i=\frac{y_{n}-y_{n-1}}{y_{n-1}} \cdot 100 \%
$$

where:

$y_{n}$ - the level of the phenomenon in a certain period,

$y_{n-1}$ - the level of the phenomenon in the previous period.

Pearson's linear correlation coefficient is a measure of the strength of a straight line relationship between two measurable features. It is expressed by means of the following formula (Jajuga, Walesiak, 2004, pp. 348-354):

$$
r_{X Y}=\frac{C(X, Y)}{\sqrt{S_{X}{ }^{2} \cdot S_{Y}{ }^{2}}}=\frac{\sum_{i=1}^{n}\left(x_{i}-\bar{x}\right)\left(y_{i}-\bar{y}\right)}{\sqrt{\sum_{i=1}^{n}\left(x_{i}-\bar{x}\right)^{2} \cdot \sum_{i=1}^{n}\left(y_{i}-\bar{y}\right)^{2}}}=\frac{C(X, Y)}{S_{X} \cdot S_{Y}}
$$


where:

$\mathrm{C}(\mathrm{X}, \mathrm{Y})$ - covariance between the $\mathrm{X}$ and $\mathrm{Y}$ features,

$S_{X}{ }^{2}-X$ feature variance,

$S_{Y}{ }^{2}-Y$ feature variance,

$S_{X}-\mathrm{X}$ feature's standard deviation,

$S_{Y}-\mathrm{Y}$ feature's standard deviation.

The linear correlation coefficient can be considered as normalized covariance. Correlation always takes values in the range $(-1,1)$.

\section{RESEARCH RESULTS}

The standards required by grain recipients often impose requirements on transport companies that must adapt to grain transport conditions. Trucks are often subject to sanitary inspection during loading and unloading. Transport companies must keep cargo and disinfection books. Keeping the semi-trailer clean is a key element of transport. It should be cleaned after each unloading. This is extremely important when the type of grain changes. During transport, protection against moisture or dirt on the material is important. The process of loading goods must take place in neutral conditions and lasts from several minutes to several hours, depending on the method of loading. Loading can be done directly from the combine while mowing, as a charge from a silo, or from a warehouse with a loader or a grain screw conveyor. After loading, the car is weighed and transport documents are issued. During transport, it is necessary to secure the transported goods with a tarpaulin (Krzewińska, Matysek, 2012, pp. 240-246). After reaching the unloading point, the material is subjected to qualitative analysis. Unloading, similar to loading, can last from several minutes to several hours (Komplexmłyn..., 2020).

Due to grain transport standards, companies operating on the transport market are required to meet an additional condition, i.e. registration at the Poviat Sanitary Inspectorate and obtaining the so-called veterinary number. Each feed business operator must have its own universal identification number. Another requirement is to have a GMP + B4 certificate, which 
ensures the safety of grain transport. The GMP + system applies to all entities in the chain, starting from the farmer, through transport, forwarding and trade companies, to production. The GMP + certificate makes it possible to export feed goods to the European Union, regulates the rules regarding storage and transport of grain, and provides control at every stage. All means of transport must be kept clean. At least once a month, obligatory disinfection of the hold should be carried out using appropriate chemicals. The + symbol indicates the HACAAP procedure whose rules must be implemented with the GMP + system (BHPEX..., 2020; GMP+... 2020).

Grains transport in Poland was carried out mainly by road. In 2018, 30.8 million tonnes were transported in this way. For comparison, only 0.7 million tonnes were transported by rail. Some of the loads were exported or imported. The turnover of seaports in this area in 2018 amounted to 3.8 million tonnes. The significance of a given type of cargo can be determined on the basis of its share in total transport. Such calculations were made for three branches of transport taking into account the volume of loads (Fig. 1).

Fig. 1. The share of grains in the volume of cargo transported by various modes of transport in Poland in 2007-2018

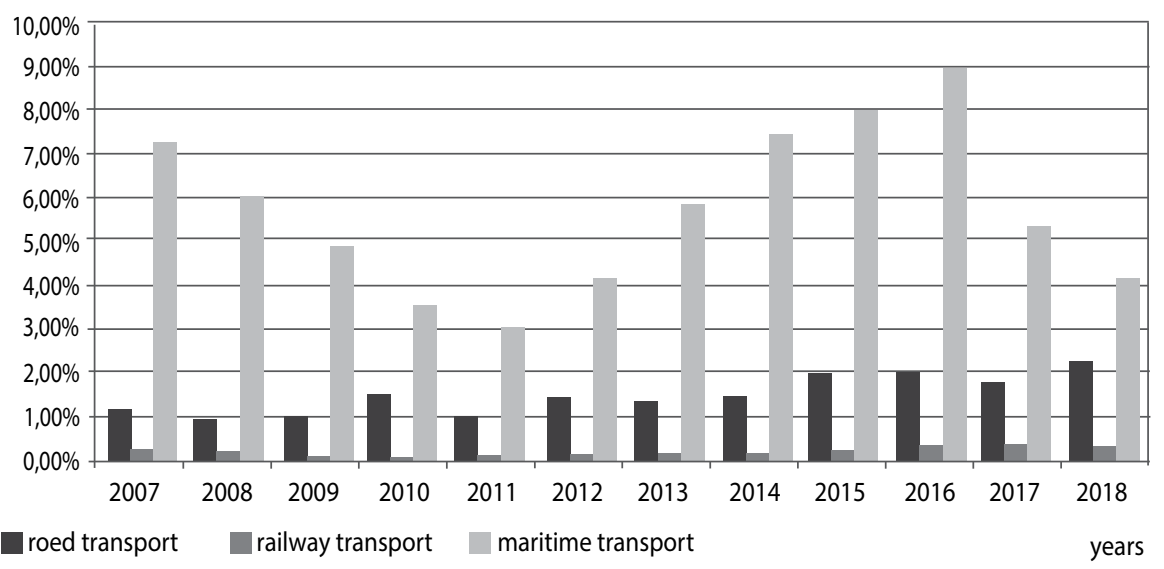

Source: own study based on Statistics Poland data. 
Grains had the largest share in sea transport, because they accounted for 3 to $9 \%$ of all goods handled. The largest share was in 2016 (9\%), and the lowest in $2011(3.07 \%)$. The transport of grains by road accounted for tens of millions of tonnes, but in volume for all loads transported by this branch of transport it was only $1-2 \%$. One can see an increase in the importance of grains in the transport of goods by road, especially since 2015. Similarly, since 2015, grain transport by rail has relatively increased, but it was still $0.30 \%$ of all cargo transported by this branch. Taking into account transport performance, the regularities were similar (Fig. 2) - both the share of grains in total transport, as well as changes in this respect.

Fig. 2. The share of grains in transport performance in tkm performed by various modes of transport in Poland in 2007-2018

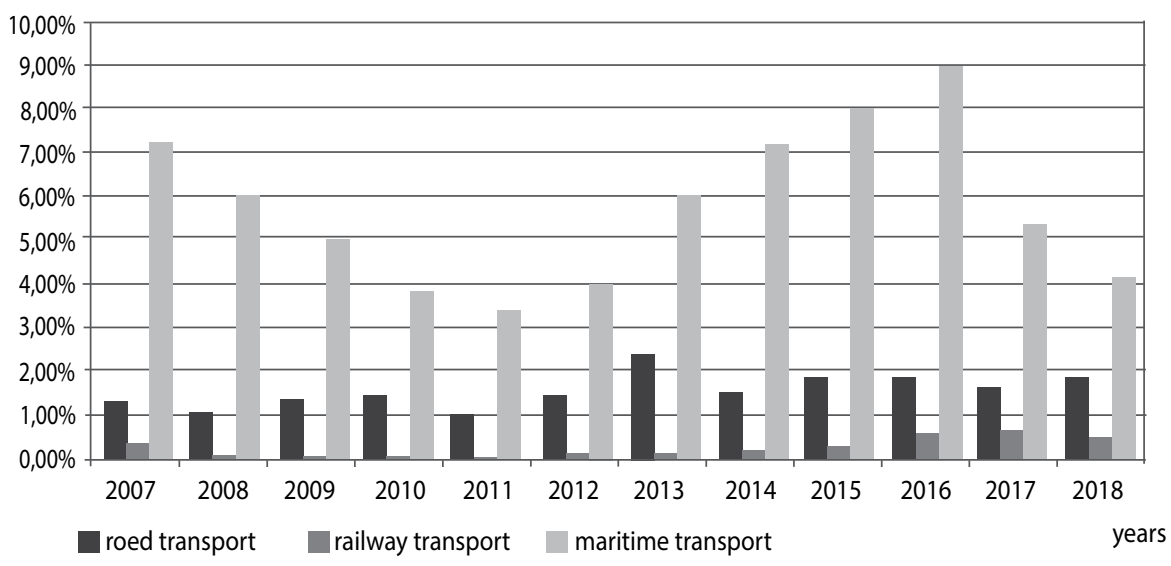

Source: own study based on Statistics Poland data.

This is due to small changes in the average distance of grain transport in individual branches. For road transport, it was between $148 \mathrm{~km}$ (in 2013) and $187 \mathrm{~km}$ (2009). For rail transport it was from $98 \mathrm{~km}$ (in 2008) to 828 $\mathrm{km}$ (2016). The scale of grain transport by rail, however, was small, hence the change in transport distance did not cause large changes in the share of this load in the total transport work performed. In the years 2016-2018, the average distances ranged from $700-800 \mathrm{~km}$, which means that most of the transport concerned international routes. Polish seaports have become more 
attractive for grain exporters from Central and Eastern Europe, such as the Czech Republic, Slovakia and Hungary. This is also evidenced by changes in the structure of the volumes of grains handled in Polish seaports (Fig. 3). Grain loading, which was exported to other countries of the world, began to dominate. The conditions offered by Polish ports were competitive to German ports. Polish ports systematically invest in improving the conditions and possibilities of cargo handling, which results in greater interest of contractors from other countries.

Fig. 3. Share of loading and unloading in the volume of grains handled in Polish seaports in 2007-2018

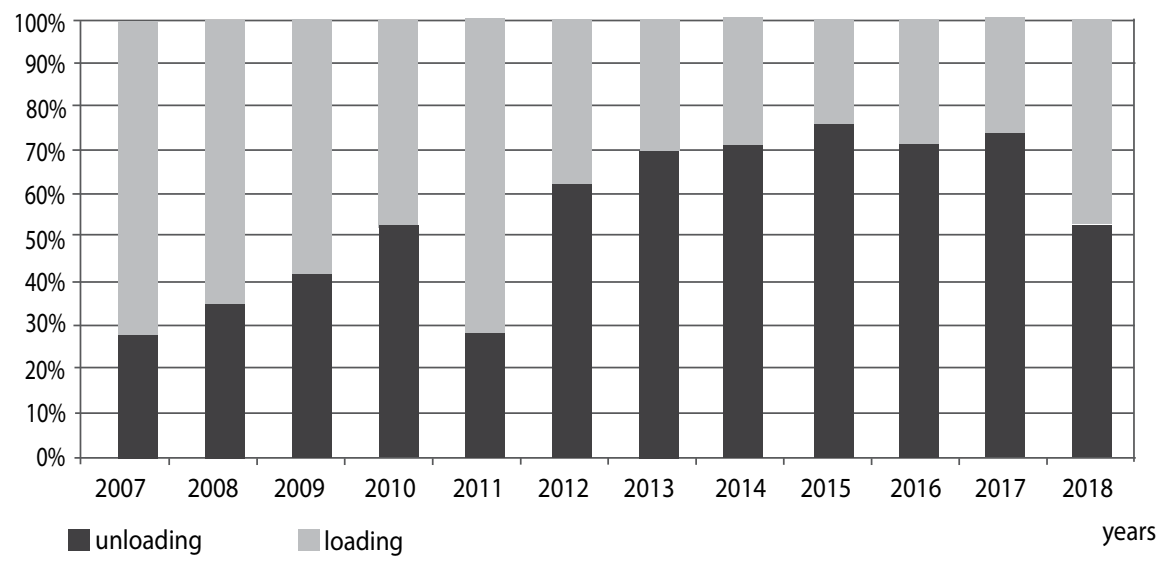

Source: own study based on Statistics Poland data.

In the years 2007-2018, the volume of grains transport by car increased by $175 \%$, by rail increased by $43 \%$, and by sea was maintained at a similar level. This shows the changes taking place with regard to the transport of this load. However, in individual years, there were large fluctuations in the volume of grains transported (Table 1). Carriage of grains by car increased steadily. Only in three years there was a decline. The coefficient of variation in the examined period for this branch of transport was $36 \%$, which meant quite large fluctuations and instability of the volume of grain transport by road. In rail transport, the increase in the volume of grain transport prevailed, only in three years there was a decrease. However, the changes were rapid, as 
evidenced by the high coefficient of variation of $61 \%$. This result was affected by 2009 , when as a result of the economic crisis rail grain transport fell by $80 \%$. In subsequent years, there was a systematic increase in grain transport by rail. In maritime transport, the period of declines followed by years of increases and declines again. The coefficient of variation was $37 \%$, which indicates low stability.

Table 1 Dynamics indicators for the volume of grain transport in individual modes of transport in 2007-2018

\begin{tabular}{|c|c|c|c|}
\hline \multirow{2}{*}{ Years } & \multicolumn{3}{|c|}{$\begin{array}{c}\text { Dynamics indicators for the volume of grain transport in the modes of transport } \\
\text { (previous year = 100) }\end{array}$} \\
\cline { 2 - 4 } & road & rail & martime \\
\hline 2007 & 100,00 & 100,00 & 100,00 \\
\hline 2008 & 88,96 & 81,95 & 84,14 \\
\hline 2009 & 114,88 & 20,05 & 80,31 \\
\hline 2010 & 164,01 & 132,10 & 82,92 \\
\hline 2011 & 69,19 & 151,40 & 83,07 \\
\hline 2012 & 135,29 & 115,43 & 140,92 \\
\hline 2013 & 82,27 & 129,41 & 152,20 \\
\hline 2014 & 126,99 & 116,94 & 135,66 \\
\hline 2015 & 134,25 & 147,35 & 108,37 \\
\hline 2016 & 106,19 & 163,31 & 117,60 \\
\hline 2017 & 101,56 & 111,60 & 63,78 \\
\hline 2018 & 116,00 & 92,89 & 90,90 \\
\hline
\end{tabular}

Source: own study based on Statistics Poland data.

There are several terminals in Poland, as part of seaports, dedicated to handling grain. The Baltic Grain Terminal had the capacity to store 71 thousand tonnes of goods. He had flat warehouses, silos and an elevator [Baltic..., 2020]. The terminal also provides service in accordance with HACCP and GMP + standards. The possibility of unloading 400 tonnes of grain per hour from the ship to the warehouse was declared. The second transhipment terminal in Gdynia HES declared a warehouse capacity of about 330 thousand $\mathrm{m}^{3}$, of which $2 / 3$ were covered warehouses. The 
transhipment capacity was 40 thousand tonnes per day. The third terminal in Gdynia OT Port declared reloading capacity of 2 million tonnes per year [OT Port Gdynia, 2020]. All terminals maintained HACCP and GMP + standards. In Poland, ports in Gdansk, Szczecin and Świnoujście were still handling grain. The port in Szczecin had four grain storage elevators, with the capacity to store up to 145,000 . tons of grain cargo and 200 thousand tons of coal. OT Port Świnoujście enabled storage of up to 156 thousand tonnes of cargo and loading capacity 25,000 tons of goods per ship per day [OT Port Świnoujście, 2020; Management Board..., 2020]. At the same time, the port of Gdansk offered the deepest draft provided for ships entering the Baltic Sea, which allowed the reception of Capesize vessels with a draft of 15 meters. For comparison, ports in the west of Poland, i.e. Szczecin and Świnoujście, accepted ships with a maximum draft of $13.2 \mathrm{~m}$ [Port..., 2020].

Transhipments at seaports in 2007-2018 show the changes to which the grain market in Poland is subject in international trade. In the analyzed period, $95-99 \%$ of grains that were transhipped in seaports were traded internationally. The significance of the port of Gdynia has systematically increased. Its share in grain transhipment increased from 37 to 66\% (Fig. 4).

Fig. 4. Share of seaports in the volume of transshipment of grains in Poland in 2007-2018

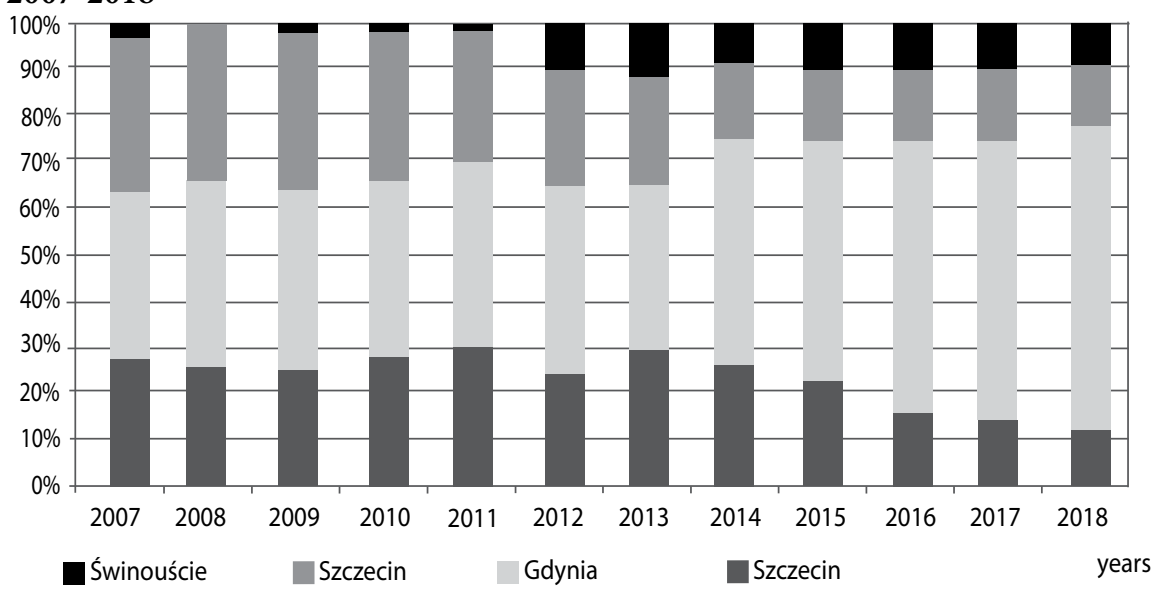

Source: own study based on Statistics Poland data. 
The importance of the port in Świnoujście has also increased. However, the share of ports in Gdańsk and Szczecin decreased. In the years 2007-2018, the structure of transhipments also changed, i.e. in most ports the share of grain unloading (from imports) decreased in favor of loading (for exports). These changes were especially visible in the transshipments of ports in Gdańsk and Gdynia. These ports have become attractive terminals used by other countries to export their grain.

Fig. 5. Share of unloading in the volume of transhipment of grains in Polish seaports in 2007-2018

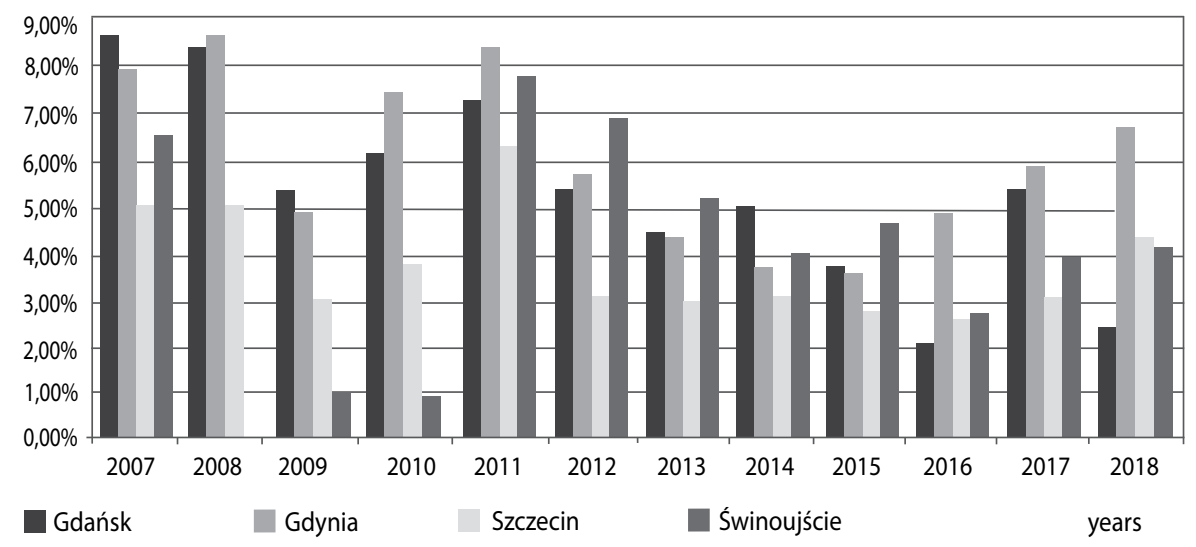

Source: own study based on Statistics Poland data.

In 2007-2018, grain handling in Świnoujście increased by 266\%. Despite such changes, the volume of turnover was still low. In Gdynia, the increase was as high as $126 \%$. Declines were recorded in the ports of Gdańsk (by 47\%) and Szczecin (by 46\%). However, in individual years there were large fluctuations in the volume of grains handled in seaports. The most difficult year in all ports was 2008, i.e. before the economic crisis and 2010-2011, i.e. after the crisis period (Table 2). Then there were declines. The smallest variability of grain transshipment volume was recorded in Szczecin (coefficient of variation $18 \%$ ) and Gdańsk (28\%), while the highest variability in Świnoujście (78\%) and Gdynia (44\%). Especially in Świnoujście, the changes were very rapid. The grains market is dependent on many conditions, often difficult to 
predict, such as the amount of harvest, economic situation on world markets, state policy, etc. Therefore, in subsequent successive years, there were large fluctuations in the volume of grain handling and transport.

Table 2. Dynamics indicators for the volume of transshipment of grains in Polish seaports in 2007-2018

\begin{tabular}{|c|c|c|c|c|}
\hline \multirow{2}{*}{ Years } & \multicolumn{4}{|c|}{$\begin{array}{c}\text { Dynamics indicators for the volume of grain handling in sea ports } \\
\text { (previous year = 100) }\end{array}$} \\
\cline { 2 - 5 } & Gdańsk & Gdynia & Szczecin & Swinoujście \\
\hline 2007 & 100,00 & 100,00 & 100,00 & 100,00 \\
\hline 2008 & 79,40 & 95,32 & 88,21 & 4,91 \\
\hline 2009 & 129,17 & 130,24 & 135,88 & 1058,49 \\
\hline 2010 & 97,15 & 82,17 & 82,33 & 86,27 \\
\hline 2011 & 97,06 & 95,68 & 82,04 & 34,92 \\
\hline 2012 & 90,25 & 118,42 & 97,33 & 2265,68 \\
\hline 2013 & 162,81 & 125,69 & 105,95 & 144,76 \\
\hline 2014 & 111,59 & 159,77 & 101,36 & 96,81 \\
\hline 2015 & 90,26 & 109,53 & 99,23 & 129,99 \\
\hline 2016 & 79,96 & 122,85 & 115,88 & 102,37 \\
\hline 2017 & 69,61 & 81,69 & 74,42 & 79,12 \\
\hline 2018 & 66,20 & 88,66 & 74,54 & 70,03 \\
\hline
\end{tabular}

Source: own study based on Statistics Poland data.

In order to determine the relationship between changes in the volume of transported grain and the economy and production potential in agriculture, Pearson's linear correlation coefficients were calculated (Table 3). $\mathrm{P}=0.05$ was used as the limit of significance. Important results are marked in bold. Correlation coefficients were calculated for the entire study period, i.e. in the years 2007-2018 The study attempted to check the correlation, which does not indicate that a given factor affects another, but that there is a strong or weak relationship between them. It was found that there are very strong positive relationships between all economy parameters and the volume of grains transport by road and rail as well as total transport. In the case of transhipments made in seaports, the results were not statistically significant. 
Table 3. Pearson's linear correlation coefficients between the parameters of the economy and the volume of grain transported within individual modes of transport

\begin{tabular}{|c|c|c|c|c|c|c|c|c|}
\hline \multirow{3}{*}{ Tested parameters } & \multicolumn{8}{|c|}{ Pearson's linear correlation coefficients } \\
\hline & \multicolumn{2}{|c|}{ road transport } & \multicolumn{2}{|c|}{$\begin{array}{c}\text { railway trans- } \\
\text { port }\end{array}$} & \multicolumn{2}{|c|}{$\begin{array}{c}\text { maritime trans- } \\
\text { port }\end{array}$} & \multicolumn{2}{|c|}{ transport total } \\
\hline & $\mathbf{r}$ & p-value & $\mathbf{r}$ & p-value & $\mathbf{r}$ & p-value & $\mathbf{r}$ & p-value \\
\hline \multicolumn{9}{|c|}{ Correlation coefficients between the lamb meat prices and } \\
\hline GDP & 0.894 & 0.001 & 0.671 & 0.017 & 0.465 & 0.128 & 0.880 & 0.001 \\
\hline GDP per capita & 0.889 & 0.001 & 0.679 & 0.015 & 0.469 & 0.124 & 0.876 & 0.001 \\
\hline $\begin{array}{l}\text { Final consumption } \\
\text { of households }\end{array}$ & 0.860 & 0.001 & 0.601 & 0.039 & 0.396 & 0.203 & 0.836 & 0.001 \\
\hline $\begin{array}{c}\text { Final consumption } \\
\text { of households } \\
\text { per capita }\end{array}$ & 0.863 & 0.001 & 0.609 & 0.036 & 0.419 & 0.175 & 0.843 & 0.001 \\
\hline $\begin{array}{l}\text { Export of goods } \\
\text { and services }\end{array}$ & 0.925 & 0.001 & 0.925 & 0.001 & 0.537 & 0.072 & 0.922 & 0.001 \\
\hline $\begin{array}{l}\text { Import of good } \\
\text { and services }\end{array}$ & 0.900 & 0.001 & 0.733 & 0.007 & 0.475 & 0.119 & 0.889 & 0.001 \\
\hline $\begin{array}{l}\text { Global agricultural } \\
\text { production }\end{array}$ & 0.859 & 0.001 & 0.729 & 0.007 & 0.553 & 0.062 & 0.867 & 0.001 \\
\hline Grain sown area & -0.648 & 0.023 & -0.260 & 0.414 & -0.544 & 0.068 & -0.663 & 0.019 \\
\hline Grain harvest & 0.213 & 0.506 & 0.197 & 0.539 & 0.454 & 0.138 & 0.273 & 0,391 \\
\hline
\end{tabular}

Source: own study.

Another account concerned grain transport with various transport modes and parameters related to agriculture. A very strong significant positive correlation was found in the case of the value of global agricultural production for all branches except sea transport. Parameters specific to grains were generally not significant. Only a strong negative correlation was found between the grains sown area and total grains transport and road transport of this load. The grains harvest was insignificant. With the development of the economy, grain has become a market product offered on a global and not just local scale. The volume of transport is often determined by the dynamics of international trade. 


\section{Discussion}

Research shows that grain turnover in seaports is due to the global economic situation. The reduction of competitors' grain production increases the export and transport of grains in a given region. Climate change also has a significant impact on the transport of grains production and transport (Fuller et al., 2012, pp. 51-69; Attavanich et al., 2013, pp. 638-643; Villavicencio et al., 2013, pp. 815-824; Mccarl et al., 2016, pp. 321-344). The modes of transport used are also changing. Road and rail transport are increasing, and sea transport is decreasing (Attavanich et al., 2011, pp. 2-53). Improved results are also influenced by better transport infrastructure in the form of roads and routes and transhipment terminals (Fuller et al., 2003, pp. 61-85; Costa et al., 2007, pp. 28-35; Oliveira et al., 2013, pp. 1-24). An important factor affecting grain transport volumes is the change in demand in particular regions and countries of the world for grain products (DeVuyst et al., 2009, pp. 472-485; Henrickson, 2011, pp. 1257-1269). Another factor is the use of grain for other purposes, e.g. for ethanol production. International competition in the field of grain trade is also systematically increasing (Wilson et al., 2005, pp. 22-30; Bojnec and Ferto, 2009, pp. 327-337; 2015, pp. 476-492; 2016, pp. 1173-1185; 2019, pp. 635-650; Carraresi and Banterle, 2015, pp. 37-62).

\section{Conclusions}

The transport of grains requires many procedures that are important due to the quality of the raw material being transported. Grains are the subject of exchange on a local, national and international scale, being an important raw material for food processing. For transporting grains, branches of transport are used to transport bulk cargo, i.e. road, sea and rail transport. Of these, the largest volume was transported by road, then by sea and rail. However, grains were the most important in a given branch in maritime transport (from 3 to $9 \%$ of total transport in this branch), then in road (1-2\%) and rail $(0.30 \%)$. The average transport distance in road transport was about $150-180 \mathrm{~km}$. It was similar in rail transport, however, since 2016, the distance has increased to $800 \mathrm{~km}$. This was caused by the increase in grain exports using Polish seaports. 
In the years 2007-2018, the volume of grains transported by road, by rail, and by sea increased the fastest. However, in individual years there were large fluctuations in the volume of grains transported, for road transport the coefficient of variation was $36 \%$, rail $61 \%$ and sea $37 \%$. From the point of view of international trade in grain, the decisive factor is sea transport, which transported more and more of this raw material. In Poland, there are terminals dedicated to this type of transport. They are located in the largest seaports, i.e. in Gdańsk, Gdynia, Szczecin and Świnoujście. The importance of ports in Gdynia and Świnoujście was systematically increasing, while for the others it was decreasing. In most ports, the share of grain unloading (from imports) has decreased in favor of loading (for exports). Polish ports have become attractive terminals used by other countries to export their grain. The variability in the volume of processed grain varied, it was the largest in Świnoujście and Gdynia, and small in Szczecin and Gdańsk.

The research hypothesis, according to which there was a strong linear relationship between the volume of grain transported and the economic situation in Poland was confirmed. The exception was sea transport, for which no significant relationships were found. This means that the economic situation has a major impact on grain trade. A very strong significant positive correlation was found in the case of the value of global agricultural production for all branches except sea transport. Parameters specific to grains were generally not significant. Only a strong negative correlation was found between the grains sown area and total grains transport and road transport of this load. The grains harvest was insignificant. The achieved result means that grain has become a market product, the object of international trade, and parameters related to agriculture have become insignificant.

\section{References}

Attavanich, W., McCarl, B. A., Ahmedov, Z., Fuller, S. W., Vedenov, D. V. (2013). Effects of climate change on US grain transport. Nature Climate Change, 3(7), pp. 638-643. ISSN 1758-678X.

Attavanich, W., McCarl, B. A., Fuller, S. W., Vedenov, D. V., Ahmedov, Z. (2011). The effect of climate change on transportation flows and inland waterways due to climate-induced shifts in crop production patterns, Agricultural and Applied Eco- 
nomics Association (AAEA) 2011 Annual Meeting, July 24-26, 2011, Pittsburgh, Pennsylvania, No. 321-2016-10670, pp. 2-53.

Baltic Grain Terminal. Obtained (15.06.2020) from http://www.btz.gdynia.pl/o-spolce/

Berner, B., Hantz, K., Chojnacki, J., Grieger, A. (2015). Środki transportowe do przewozu płodów rolnych. Autobusy: technika, eksploatacja, systemy transportowe, 16, ss. 33-36. ISSN 1509-5878.

BHPEX Wielgus Spółka Jawna. Obtained (15.06.2020) from https://www.bhpex.pl/ blog/bezpieczenstwo-zywnosci/system-haccp/.

Bojnec, S., Ferto, I. (2009). Determinants of agro-food trade competition of Central European countries with the European Union. China Economic Review, 20(2), pp. 327-337. ISSN 1043-951X.

Bojnec, S., Ferto, I. (2015). Agri-food export competitiveness in European Union countries. Journal of Common Market Studies, 53(3), pp. 476-492. ISSN 0021-9886.

Bojnec, S., Ferto, I. (2016). Drivers of the duration of grain competitiveness in European Union countries. Journal of Agricultural Science and Technology, 18(4), pp. 1173-1185. ISSN 1680-7073.

Bojnec, S., Ferto, I. (2019). European Union countries agri-food trade structures and main competitors on the internal and global agri-food markets. Economics of Agriculture, 66(2), pp. 635-650. ISSN 1574-0862.

Carraresi, L., Banterle, A. (2015). Agri-food competitive performance in EU countries: A fifteen-year retrospective. International Food and Agribusiness Management Review, 18(1030-2016-83063), pp. 37-62. ISSN 1559-2448.

Costa, R. D. F., Rosson, C. P., Costa, E. D. F. (2007). Decreasing Brazil's Transportation Costs Through Improvement in Infrastructure: A General Equilibrium Analysis on the Soybean Complex World Market. Journal of Food Distribution Research, 38(856-2016-57904), pp. 28-35. ISSN 2643-3354.

DeVuyst, E., Wilson, W. W., Dahl, B. (2009). Longer-term forecasting and risks in spatial optimization models: The world grain trade. Transportation Research Part E: Logistics and Transportation Review, 45(3), pp. 472-485. ISSN 1366-5545.

Fuller, S., Yu, T. H., Fellin, L., Lalor, A., Krajewski, R. (2003). Effects of improving transportation infrastructure on competitiveness in world grain markets. Journal of International Food \& Agribusiness Marketing, 13(4), pp. 61-85. ISSN 0897-4438.

Fuller, S., Millerd, F., Fraire, F., do Carmo Alfonso, M. (2012). Analysis of factors influencing grain traffic on the St. Lawrence Seaway. Journal of the Transportation Research Forum, Vol. 48, No. 2, pp. 51-69. ISSN 1046-1469. 
Gholamian, M. R., Taghanzadeh, A. H. (2017). Integrated network design of wheat supply chain: A real case of Iran. Computers and Electronics in Agriculture, 140, pp. 139-147. ISSN 0168-1699.

GMP+ International. Obtained (15.06.2020) from https://www.gmpplus.org/pl/certification/.

Henrickson, K. E. (2011). Spatial competition and geographic grain transportation demand on the Mississippi and Illinois rivers. Applied Economics, 43(10), 1257-1269. ISSN 0003-6846.

Jajuga, K., Walesiak, M. (2004). Remarks on the Dependence Measures and the Distance Measures, (in:) Jajuga K., Walesiak M. (ed.), Klasyfikacja i analiza danych - teoria i zastosowania, Prace Naukowe Akademii Ekonomicznej we Wrocławiu nr 1022, AE, Wrocław, pp. 348-354.

Komplexmlyn. Wymagania dla dostawców zbóż oraz nasion i roślin straczkowych. Obtained (05.07.2020) from http://komplexmlyn.com.pl/wp-content/uploads/2017/08/ Wymagania-dla-dostawc\%C3\%B3w-zb\%C3\%B3\%C5\%BC-wersja-2.pdf.

Krzewińska, A., Matysek, K. (2012). Wymagania Stawiane Środkom Transportu Żywności, Autobusy: technika, eksploatacja, systemy transportowe, 13, ss. 240-246. ISSN 1509-5878.

Mccarl, B. A., Thayer, A. W., Jones, J. P. (2016). The challenge of climate change adaptation for agriculture: An economically oriented review. Journal of Agricultural and Applied Economics, 48(4), pp. 321-344. ISSN 1074-0708.

Mogale, D. G., Dolgui, A., Kandhway, R., Kumar, S. K., Tiwari, M. K. (2017a). A multi-period inventory transportation model for tactical planning of food grain supply chain. Computers \& Industrial Engineering, 110, pp. 379-394. ISSN 03608352.

Mogale, D. G., Kumar, S. K., Márquez, F. P. G., Tiwari, M. K. (2017b). Bulk wheat transportation and storage problem of public distribution system. Computers \& Industrial Engineering, 104, pp. 80-97. ISSN 0360-8352.

Mogale, D. G., Kumar, M., Kumar, S. K., Tiwari, M. K. (2018). Grain silo location-allocation problem with dwell time for optimization of food grain supply chain network. Transportation Research Part E: Logistics and Transportation Review, 111, pp. 40-69. ISSN 1366-5545.

Naderi, B., Govindan, K., Soleimani, H. (2019). A Benders decomposition approach for a real case supply chain network design with capacity acquisition and transporter planning: wheat distribution network. Annals of Operations Research, pp. 1-21. ISSN 0254-5330. 
Oliveira, A. L. R. D., Silveira, J. M. (2013). Restructuring of the corn supply chain in Brazil: facing the challenges in logistics or regulation of biotechnology. International Food and Agribusiness Management Review, 16(4), pp. 1-24. ISSN 1559-2448.

OT Port Gdynia Sp. $z$ o. o. Obtained (15.06.2020) from https://www.otpg.pl/co-robimy/\#section3.

OT Port Śiwnoujście S. A. Obtained (15.06.2020) from http://www.otport.swinoujscie.pl/pl/terminal-masowy.html.

Port Pótnocny Sp. z o. o. Obtained (15.06.2020) from http://www.port-polnocny.pl/ terminal_importowy.html.

Villavicencio, X., McCarl, B. A., Wu, X., Huffman, W. E. (2013). Climate change influences on agricultural research productivity. Climatic change, 119(3-4), pp. 815-824. ISSN 0165-0009.

Wilson, W. W., Koo, W. W., Taylor, R., Dahl, B. (2005). Long-term forecasting of world grain trade and US gulf exports. Transportation research record, 1909(1), pp. 22-30. ISSN 0361-1981.

Starzyńska, W. (2002). Statystyka praktyczna . Wydawnictwo Naukowe PWN, Warszawa, 2002, p. 102.

Szwedziak, K., Tukiendorf, M. (2015). Łańcuch przepływu prac technologicznych w transporcie zbóż w magazynach. Logistyka, 4, CD, ss. 6092-6099. ISSN 12315478.

Zarząd Morskich Portów Szczecin i Świnoujście S. A. Obtained (15.06.2020) from http://www.port.szczecin.pl/pl/oferta/us\%C5\%82ugi-portowe/\%C5\%81adunki-masowe/ 
